\title{
Luteotrophic effect of the rabbit blastocyst
}

\author{
M. M. Singh* and C. E. Adam \\ A.R.C. Institute of Animal Physiology, Animal Research Station, \\ 307 Huntingdon Road, Cambridge CB3 OJQ, U.K.
}

\begin{abstract}
Summary. Progesterone concentrations in peripheral plasma of 27 rabbits were determined by radioimmunoassay daily from Days 1 to 7 . The rate of increase was significantly higher in pregnant than in pseudopregnant rabbits from Days 5 to $7(P<0.02)$, but not before Day 5. Transfer of Day-4 or -5 blastocysts to synchronous, pseudopregnant recipients resulted in a significant rise in progesterone levels in comparison with those in sham-operated controls $(P<0.01)$ or pseudopregnant does $(P<0.01)$.
\end{abstract}

\section{Introduction}

Fuchs \& Beling (1974) reported that plasma progesterone levels were significantly higher in pregnant than in pseudopregnant rabbits from Day 5 up to Day 10. They suggested, therefore, that the ovary recognizes the presence of blastocysts before implantation (Day 7), thereby implying that the blastocyst can exert a luteotrophic influence. This concept gained support from the finding that, when blastocysts were transferred to pseudopregnant recipients on Days 4 or 5, plasma progesterone concentrations were increased significantly compared with levels in intact, pseudopregnant controls (Fuchs, Beling \& Park, 1974). However, Holt, Heise, Wilson \& Keyes (1976) found that serum progesterone concentrations were not different in pregnant and pseudopregnant does before Day 7 , although they were higher 4 or 5 days later.

The present work was undertaken in an attempt to clarify these apparently conflicting findings.

\section{Materials and Methods}

Adult female rabbits, weighing $3 \cdot 5-4 \mathrm{~kg}$ and from our own colony, were mated with fertile or vasectomized (sterile) males. All the does were given an intravenous injection of $25 \mathrm{i}$.u. hCG (Gonadotrophon: Paines \& Byrne Ltd, Greenford, Middlesex) shortly after mating (Day 0) and allocated to treatment groups as follows. Group A contained 5 does mated with fertile males. Groups B-F contained 22 does mated with sterile males: Group B consisted of 4 does; the 6 pseudopregnant does in each of Groups $\mathrm{C}$ and $\mathrm{E}$ each received 4-8 blastocysts from synchronized donors on Day 4 (Group C) or Day 5 (Group E); the 3 pseudopregnant does in each of Groups D and F were treated similarly on Days 4 and 5 respectively but received no blastocysts (sham transfer).

For transfer of blastocysts or saline only the animals in Groups C-F were anaesthetized with sodium pentobarbitone (Nembutal: Abbott Laboratories, Queensborough, Kent) given intravenously and halothane (Fluothane: Imperial Chemical Industries, Macclesfield, Cheshire) in nitrous oxide via a face mask. The ovaries were examined before transfer to verify that ovulation had occurred. The blastocysts were obtained from donors on Days 4 or 5 by flushing the excised uteri with $5 \mathrm{ml} 0.9 \%$ $(\mathrm{w} / \mathrm{v}) \mathrm{NaCl}$ solution at $37^{\circ} \mathrm{C}$ and were transferred almost immediately to both uterine horns.

Animals in Groups A and B were examined by laparotomy on Day 10 to establish the presence of conceptuses and/or corpora lutea.

Blood samples ( $2-3 \mathrm{ml}$ ) were collected daily from a marginal ear vein into heparinized tubes from the rabbits in all groups on Days 1-7 inclusive; on the day of laparotomy, samples were taken before any other treatment. After centrifugation of the blood for $10 \mathrm{~min}$ at $1600 \mathrm{~g}$, the plasma was removed

\footnotetext{
* Present address: Division of Endocrinology, Central Drug Research Institute, Lucknow, India.
} 
and stored initially at $-20^{\circ} \mathrm{C}$ and then at $-70^{\circ} \mathrm{C}$ for not more than 3 months before assay. The plasma was extracted with $n$-hexane ( $>90 \%$ efficiency) and the progesterone content of the extract was measured by the radioimmunoassay method described by O'Grady, Caldwell, Auletta \& Speroff (1972). The ant iserum was ICI $465 / 5$ and its cross-reactivity, estimated at $50 \%$ displacement of labelled progesterone, was less than $1.3 \%$ for all the major steroids, except for pregnenolone $(3.4 \%)$, as described by Newcomb, Booth \& Rowson (1977). Each assay contained three blanks and 6 standards (0.1-4 mg progesterone) in duplicate. Approximately $20 \%$ of the extracted samples were duplicated. The limit of sensitivity of the assay was $0.01 \mathrm{ng} / \mathrm{ml}$.

The data were examined by carrying out analyses of variance of the progesterone values for Days 1-7 individually, and also by conducting similar analyses on functions of the progesterone values over time, e.g. the rate of increase per day over specified periods.

\section{Results}

In the 5 Group-A females the mean litter size was $7 \cdot 6$ (range 3-12) whilst in females of Groups $C$ and E, which received means of $6 \cdot 3$ and $5 \cdot 3$ blastocysts, it was $4 \cdot 2(1-8)$ and $2 \cdot 1(1-3)$ respectively.

The concentrations of plasma progesterone in does in Groups A-F during Days 1 to 7 are given in Table 1. The overall mean value (Days 1-7) for the pregnant does (Group A) was significantly higher than that for the pseudopregnant does (Group B). The estimated difference was $1.89 \pm 0.41 \mathrm{pg}$. The difference remained quite small for the first 5 days but thereafter the values diverged. The rate of increase of progesterone concentration during Days 5-7 was $2.21 \pm 0.64 \mathrm{pg} /$ day (Group A) and 0.08 \pm $0.08 \mathrm{pg} /$ day (Group B) $(P<0.02)$.

Transfer of blastocysts on Days 4 or 5 (Groups $C$ and $E$ ) resulted in a significant increase in plasma progesterone concentration compared with the levels found in the sham-operated (Groups D and F, $P<0.01$ ) or pseudopregnant does (Group B, $P<0.01$ ). This effect of the presence of blastocysts was discernible within $24 \mathrm{~h}$ of transfer (Table 1). A comparison of the pseudopregnant (Group B) with the sham-operated animals (Groups D and F) for Days 5-7 failed to reveal any significant differences.

Table 1. Plasma progesterone concentrations ( $\mathrm{ng} / \mathrm{ml}$, mean \pm s.e.m.) in pregnant and pseudopregnant rabbits

\begin{tabular}{|c|c|c|c|c|c|c|c|c|c|}
\hline \multirow[b]{2}{*}{ Group } & \multirow[b]{2}{*}{ Treatment } & \multirow{2}{*}{$\begin{array}{l}\text { No. of } \\
\text { does }\end{array}$} & \multicolumn{7}{|c|}{ Days } \\
\hline & & & 1 & 2 & 3 & 4 & 5 & 6 & 7 \\
\hline A & Pregnant & 5 & $\begin{array}{c}1 \cdot 24 \pm \\
0.16\end{array}$ & $\begin{array}{c}2 \cdot 26 \pm \\
0.25\end{array}$ & $\begin{array}{c}3.90 \pm \\
0.37\end{array}$ & $\begin{array}{c}4.72 \pm \\
0.26\end{array}$ & $\begin{array}{c}6.22 \pm \\
0.38\end{array}$ & $\begin{array}{c}7.06 \pm \\
0.69\end{array}$ & $\begin{array}{c}10 \cdot 84 \pm \\
1.23\end{array}$ \\
\hline B & Pseudopregnant & 4 & $\begin{array}{c}0.75 \pm \\
0.10\end{array}$ & $\begin{array}{c}1 \cdot 35 \pm \\
0.22\end{array}$ & $\begin{array}{c}2.03 \pm \\
0.37\end{array}$ & $\begin{array}{c}4.00 \pm \\
0.49\end{array}$ & $\begin{array}{c}4.90 \pm \\
0.94\end{array}$ & $\begin{array}{c}4.93 \pm \\
0.80\end{array}$ & $\begin{array}{l}5.05 \pm \\
0.82\end{array}$ \\
\hline $\mathrm{C}$ & $\begin{array}{l}\text { Day } 4 \text { blastocysts } \\
\text { transferred }\end{array}$ & 6 & $\begin{array}{c}1 \cdot 30 \pm \\
0.13\end{array}$ & $\begin{array}{c}2.88 \pm \\
0.61\end{array}$ & $\begin{array}{c}3.93 \pm \\
0.40\end{array}$ & $\begin{array}{c}4 \cdot 37 \pm \\
0.38\end{array}$ & $\begin{array}{c}7 \cdot 08 \pm \\
0.74\end{array}$ & $\begin{array}{c}7.42 \pm \\
0.71\end{array}$ & $\begin{array}{c}8.58 \pm \\
0.65\end{array}$ \\
\hline D & $\begin{array}{l}\text { Sham transfer } \\
\text { Day } 4\end{array}$ & 3 & $\begin{array}{c}1.20 \pm \\
0.60\end{array}$ & $\begin{array}{c}1 \cdot 37 \pm \\
0.38\end{array}$ & $\begin{array}{c}2.47 \pm \\
0.57\end{array}$ & $\begin{array}{c}4.33 \pm \\
0.70\end{array}$ & $\begin{array}{c}5 \cdot 20 \pm \\
0.60\end{array}$ & $\begin{array}{c}5 \cdot 43 \pm \\
0.70\end{array}$ & $\begin{array}{l}5 \cdot 70 \pm \\
0.55\end{array}$ \\
\hline $\mathrm{E}$ & $\begin{array}{l}\text { Day } 5 \text { blastocysts } \\
\text { transferred }\end{array}$ & 6 & $\begin{array}{c}1.08 \pm \\
0.12\end{array}$ & $\begin{array}{c}1 \cdot 82 \pm \\
0 \cdot 14\end{array}$ & $\begin{array}{c}2 \cdot 88 \pm \\
0.20\end{array}$ & $\begin{array}{c}4.92 \pm \\
0.39\end{array}$ & $\begin{array}{c}5.77 \pm \\
0.40\end{array}$ & $\begin{array}{c}8.40 \pm \\
0.67\end{array}$ & $\begin{array}{c}8.77 \pm \\
0.66\end{array}$ \\
\hline $\mathrm{F}$ & $\begin{array}{l}\text { Sham transfer } \\
\text { Day } 5\end{array}$ & 3 & $\begin{array}{c}0.73 \pm \\
0.15\end{array}$ & $\begin{array}{c}2.57 \pm \\
0.27\end{array}$ & $\begin{array}{c}3.63 \pm \\
0.72\end{array}$ & $\begin{array}{c}3.27 \pm \\
0.32\end{array}$ & $\begin{array}{c}5.93 \pm \\
0.43\end{array}$ & $\begin{array}{c}6.23 \pm \\
0.34\end{array}$ & $\begin{array}{c}6.47 \pm \\
0.88\end{array}$ \\
\hline
\end{tabular}

\section{Discussion}

Our finding that plasma progesterone concentrations in pregnant does were significantly higher than in pseudopregnant does over the period Days 5-7 post coitum and that 4- and 5-day blastocysts exerted a luteotrophic effect agree closely with the earlier reports of Fuchs \& Beling (1974) and Fuchs 
et al. (1974), but not with those of Holt et al. (1976). By using a radioimmunoassay rather than a competitive protein binding method, as used by Fuchs \& Beling (1974), for measuring progesterone values and by establishing that the 'pseudopregnant' rabbits did have functional corpora lutea and the pregnant rabbits viable embryos, we have accounted for the major sources of variation in their work as advanced by Holt et al. (1976). Additionally, we have characterized the role of the blastocyst more specifically by demonstrating the lack of effect of a sham operation in elevating progesterone levels before implantation.

There is disagreement about the existence and nature of the luteotrophic signal from the blastocyst. A gonadotrophin similar to hCG or LH has been found in blood plasma, uterine fluid and blastocysts of the rabbit before implantation (Fujimoto, Woody \& Dukelow, 1973; Haour \& Saxena, 1973), and assayed in blastocysts (Fujimoto, Euker, Riegel \& Dukelow, 1975). However, Sundaram, Connell \& Passantino (1975) and Holt et al. (1976) have failed to demonstrate hCG-like activity or LH-like hormone in the preimplantation blastocyst. The present findings should serve to stimulate further investigation of this question.

This investigation received financial support from the World Health Organization in the form of a Research training grant to M.M.S. We are indebted to Mr D. Green for carrying out the progesterone determinations and to Mr D. E. Walters for the statistical analyses.

\section{References}

Fuchs, A.R. \& Beling, C. (1974) Evidence for early ovarian recognition of blastocysts in rabbits. Endocrinology 95, 1054-1058.

Fuchs, A.R., Beling, C. \& Park, K. (1974) Corpus luteum recognition of blastocysts prior to implantation. Endocrinology 95, A-167.

Fujimoto, S., Woody, H.D. \& Dukelow, W.R. (1973) Cell number and mitotic index of the rabbit blastocyst. Fedn Proc. Fedn Am. Socs exp. Biol. 32, 214.

Fujimoto, S., Euker, J.S., Riegel, G.D. \& Dukelow, W.R. (1975) On a substance cross-reacting with luteinizing hormone in the preimplantation blastocyst fluid of the rabbit. Proc. Japan Acad. 51, 123125.

Haour, F. \& Saxena, B.B. (1973) Detection of a gonadotrophin in rabbit blastocyst before implantation. Science, N.Y. 185, 444-445.
Holt, J.A., Heise, W.F., Wilson, S.M. \& Keyes, P.L. (1976) Lack of gonadotrophic activity in the rabbit blastocyst prior to implantation. Endocrinology 98 , 904-909.

Newcoms, R., Boorh, W.D. \& Rowson, L.E.A. (1977) The effect of oxytocin treatment on the levels of prostaglandin in the blood of heifers. J. Reprod. Fert. 49, 17-24.

O'Grady, J.P., Caldwell, B.V., Auletta, F.J.· \& SPEROFF, L. (1972) The effects of an inhibitor of prostaglandin synthesis (indomethacin) on ovulation, pregnancy and pseudopregnancy in the rabbit. Prostaglandins 1, 97-106.

Sundaram, K., Connell, K.G. \& Passantino, T. (1975) Implication of absence of HCG-like gonadotrophin in the blastocyst for control of corpus luteum function in pregnant rabbit. Nature, Lond. 256, 739-741.

Received 18 November 1977 